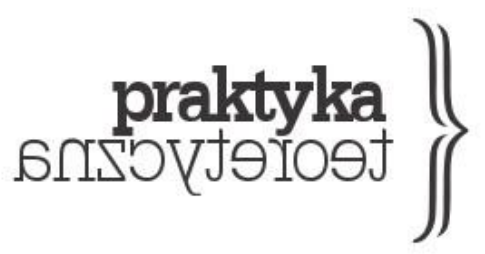

Praktyka Teoretyczna

Numer 3(25)/2017

ISSN 2081-8130

DOI: $10.14746 /$ prt.2017.3.14

www.praktykateoretyczna.pl

\title{
JAK DZIŚ SZUKAĆ LINII UJŚCIA? WSTĘP
}

JOANNA BEDNAREK, DAWID KUJAWA 
Rosnące w Polsce zainteresowanie myślą Gilles'a Deleuze’a i Féliksa Guattariego coraz bardziej zdaje się przybierać postać zmiany dominującego paradygmatu, który przez lata wyznaczała specyficznie rozumiana - to znaczy w dużej mierze przefiltrowana przez anglosaskie odczytania - dekonstrukcja ${ }^{1}$. W okresie odzyskiwania Deleuze’a jako wnikliwego czytelnika Spinozy i kartografa immanentystycznej ontologii politycznej a nie „po prostu” poststrukturalisty i filozofa różnicy, jak traktowany był on dotychczas szczególne znaczenie miały u nas nurty nowomaterialistyczne: to w dużej mierze za sprawa popularyzacji prac Rosi Braidotti, Karen Barad czy Elizabeth Grosz udało się wyprowadzić polska myśl teoretyczną poza trwające od wielu lat, i z czasem coraz mniej produktywne, próby śledzenia tropów esencjalizmu oraz zwalczania go na rzecz rzekomo zawsze wyzwalającego i politycznie skutecznego konstruktywizmu (zob. np. Grosz 2009, 23, przyp. 21; 2011; Barad 2012; Bednarek 2012, 227-230; Braidotti 2009; 2012). Ujęcia tego rodzaju (restytuujące monizm i witalizm, eksploatujące pojęcie kłącza, zacierające granice między naukami przyrodniczymi i humanistyka) nieczęsto szły jednak w parze $z$ marksistowskimi odczytaniami Kapitalizmu $i$ schizofrenii: niestety zwykle milczały one o tych watkach prac Guattariego i Deleuze'a (traktowanych tu jako kolektyw autorski i jako dwóch autorów), które szczególne znaczenie miały dla części włoskich autonomistów w latach siedemdziesiątych i później (np. pragnienie-produkcja jako produkcja biopolityczna/żywa praca, koncepcja transwersalnej podmiotowości jako impuls do redefinicji składu klasowego, przepływ semiotyczny jako podstawa pojęcia semiokapitalizmu etc.).

Z jednej więc strony, tak ustawiony punkt widzenia okazał się skuteczny w kwestii wychodzenia poza tradycyjną dialektykę, Heglowską negatywność czy Lacanowski brak wsferze politycznej prowadzi to ostatecznie między innymi do odrzucenia reprezentacjonizmu i dowartościowania horyzontalnych układów oraz działań o charakterze molekularnym. Z drugiej strony, sprawa nie jest tak prosta, jak mogłoby się wydawać: schizoanaliza, będąc maszyną wolną tak od „pierwotnego źródła”, jak i „ostatecznego celu”, może być praktykowana na różne sposoby, których nie można zdyskredytować, po prostu

1 Nie chodzi wyłącznie o lawinowo wydawane w Polsce przekłady prac Deleuze’a i Guattariego (Fałda. Leibniz a barok - Warszawa 2014, Spinoza. Filozofia praktyczna - Warszawa 2014, Tysiac platean - Warszawa 2015, Kafka. Ku literaturze mniejszej - Kraków 2016, Anty-Edyp - Warszawa 2017, Perykles i Verdi. Filozofia François Châteleta - Poznań-Warszawa 2017) oraz towarzyszące im recenzje (poza seminarium recenzyjnym Praktyki Teoretycznej poświęconym Anty-Edypowi zaplanowane zostało jeszcze jedno - zorganizowane przez redakcję Machiny Myśli seminarium o książce Kafka. Ku literaturze mniejszej). Silne inspiracje schizoanalityczne widoczne są w publikowanych ostatnio, nieraz bardzo różnych od siebie pracach z zakresu filozofii (zob. np. Michał Pospiszyl. 2017. Zatraymać historię. Benjamin i mniejszościony materializm. Warszawa: Wydawnictwo IBL PAN; Joanna Bednarek. 2015. Linie kobiecóści. Jak różnica ptciowa prz̨eksztatcita literature i filozofię? Warszawa: NCK; Fundacja na Rzecz Myślenia im. Barbary Skargi; Krzysztof Pacewicz. 2017. Fluks. Wspólnota plynón ustrojouych. Warszawa: Wydawnictwo Naukowe PWN, Fundacja na Rzecz Myślenia im. Barbary Skargi). Wspomnieć warto jeszcze o konferencji „Kiedyś nadejdzie, być może, wiek deleuzjański...” zorganizowanej przez Instytut Filozofii UW w czerwcu 2017 roku. Symptomy zmiany można by wymieniać długo - sądzimy, że dają one podstawę do postawienia tezy takiej, jak powyższa. 
powołując się na właściwe intencje Deleuze’a i Guattariego. Przykładów „nadużyć” nie trzeba daleko szukać: jest rok 2017 i obok lewicowego odłamu akceleracjonizmu (który popularność zdobyć mógł tylko dzięki całkowitemu zlekceważeniu operaistycznej koncepcji technicznego i politycznego składu klasowego i który okazuje się sporym zagrożeniem dla ruchów progresywistycznych) coraz prężniej rozwija się akceleracjonizm prawicowy (którego prominentna postacia jest Nick Land, teoretyk tak zwanego „neo-reakcjonizmu”, i któremu wiele zawdzięcza współczesna alt-prawica; [Fisher 2014; Beckett 2017]). Przedstawiciele pierwszego z tych nurtów traktują technologię i rozwój sił wytwórczych w ogóle jako coś politycznie neutralnego, co dopiero na późniejszym etapie poddawane jest politycznym formom organizacji, ich zdaniem innowacje wypracowane w ramach kapitalistycznego sposobu produkcji moga zatem z latwością zostać zaadaptowane przez społeczeństwo postkapitalistyczne (Noys 2013; Negri 2014, 373-374); drugi nurt z kolei postuluje całkowite uwolnienie procesów rynkowych spod jakichkolwiek regulacji, domaga się „,czystego” kapitalizmu (zob. Fisher 2009, 45-46), który - wsparty na „naturalnej selekcji” i nowych formach segregacji rasowej - doprowadzić ma ostatecznie do pewnego rodzaju techno-feudalizmu - obydwa zaś jako swoją zasadniczą inspirację wskazują właśnie dyskurs schizoanalityczny. To chyba najlepszy dowód na to, że samo ostrzenie narzędzi, bez uwzględnienia możliwości ich politycznego lub policyjnego zastosowania, nie otwiera jeszcze drzwi do prowadzenia emancypacyjnej polityki, a praktykowanie „niefaszystowskiego życia", o którym pisał Michel Foucault we wstępie do amerykańskiego wydania Anty-Edypa, nie musi być jedynym użytkiem czynionym z teorii schizoanalitycznej. Deterytorializacja, nawet jeśli rzeczywiście nie jest ona dziś prowadzona na wystarczająco dużą skalę, w odpowiednim momencie musi zostać zastapiona praktyką tworzenia nowych warstw, fałd, które będą już fałdami typowymi dla Nowej Ziemi, wielokrotnie wspominanej przez Deleuze'a i Guattariego. Istotną wskazówką w tej kwestii może być dla nas nieczęsto wspominany fakt: ostatnie historycznofilozoficzne dzieło Deleuze’a, którego nie zdołał on ukończyć, zatytułowane miało być Grandeur de Marx i poświęcone w całości trewirskiemu myślicielowi (Thoburn 2003, 1-15).

Teksty, które prezentujemy w ramach seminarium zorganizowanego przy okazji pierwszego polskiego wydania Anty-Edypa, pozwalają nam ocenić, jaki charakter ma współczesna recepcja schizoanalizy w Polsce, i mniej lub bardziej trafnie prognozować, w jakim kierunku recepcja ta zmierzać będzie po publikacji najważniejszego chyba i najbardziej radykalnego dzieła francuskiego duetu filozofów.

Artykuł Adriana Mrówki ma na celu przede wszystkim zwrócenie uwagi na postać Féliksa Guattariego, terapeuty, filozofa i komunisty, który tchnął nowe życie w filozofię Deleuze'a, w znaczacy sposób wpływając na radykalizację swojego wieloletniego współpracownika. Dziś wkład autora Chaosmose, bliskiego przyjaciela Antonia Negriego 
i ważnej postaci we włoskim ruchu autonomistycznym, w rozwój teorii schizoanalitycznej zbyt często pomijany jest w rozmaitych rozważaniach inspirowanych przez Kapitaližm i Schizofrenie (Mrówka 2017).

Tekst Katarzyny Szopy opiera się na zestawieniu dwóch krytyk psychoanalizy: przeprowadzonej przez Deleuze'a i Guattariego oraz feministycznej, zaproponowanej przez Luce Irigaray. Autorka Speculum, wydalona z Towarzystwa Lacanowskiego i pozbawiona posady na Uniwersytecie w Vincennes tuż po publikacji tego dzieła w 1973 roku, w wielu miejscach swojej teorii - jak przedstawia autorka - zbliża się do schizoanalitycznego ataku na Edypa (Szopa 2017).

Bartosz Mroczkowski zestawia z kolei projekt Deleuze’a i Guattariego z realizmem sprawczym Karen Barad. Wskazując na podobny sposób ujmowania ontologii w obydwu tych przedsięwzięciach, autor zwraca uwagę na odmienne założenia tkwiące u ich podstaw. Dla Barad, inaczej niż dla twórców Kapitalizmu i schizofrenii, punkt wyjścia stanowi bowiem interpretacja kopenhaska mechaniki kwantowej, przede wszystkim zaś rozważania Nielsa Bohra (Mroczkowski 2017).

Tekst Agnieszki Kotwasińskiej dotyczy zastosowań teorii schizoanalitycznej w dyskursie filmoznawczym, który w ostatnich latach dwudziestego wieku zdominowany został (przynajmniej na anglojęzycznej akademii) przez ortodoksyjną psychoanalizę. Z pozoru artykuł ten dotyczy bardzo konkretnej sytuacji w wąskim kręgu badawczym, w rzeczywistości jednak w modelowy sposób przedstawia, jak deleuzeoguattariański typ analizy umożliwia wyjście z metodologicznego impasu, zdawałoby się - nie do przezwyciężenia (Kotwasińska 2017).

Ostatni z prezentowanych artykułów dotyczy związków Anty-Edypa z filozofią Karola Marksa. Cezary Rudnicki szczególnie akcentuje silne - i zadziwiająco często pomijane - zadłużenie Deleuze'a i Guattariego w Marksowskich analizach procesu produkcji: wskazując jednoznacznie na „fabryczny” charakter nieświadomości, autor w przekonujący sposób udowadnia, że lektury pierwszego tomu Kapitalizmu i schizofrenii można dokonać bez podpierania się teoriami Freuda i Lacana, za to w oparciu o materialistyczną myśl Marksa (Rudnicki 2017).

Nie wiemy jeszcze, do czego doprowadzi wspomniana zmiana paradygmatu - kim okażą się dla polskich czytelniczek i czytelników Deleuze i Guattari, wyzwoleni z uwikłania w skojarzenie z postmodernizmem. Dzieło etyczne, „wstęp do niefaszystowskiego życia”, nieedypalna psychoanaliza, teoria kapitalizmu, materialistyczna ontologia - artykuły wchodzące w skład seminarium stanowią przykłady możliwych użyć tej pojemnej skrzynki z narzędziami, ukazując, że Anty-Edyp wciąż stanowi istotne odniesienie dla współczesnej humanistyki. 


\section{Wykaz literatury}

Barad, Karen. 2012. „Posthumanistyczna performatywność: ku zrozumieniu, jak materia zaczyna mieć znaczenie". Tłum. J. Bednarek. W Teorie wywrotowe. Antologia prz̨ekładów. Red. A. Gajewska. Poznań: Wydawnictwo Poznańskie.

Beckett, Andy. 2017. „Accelerationism: how a fringe philosophy predicted the future we live in." Guardian 11 May.

Bednarek, Joanna. 2012. „Powrót »rzeczywistości«”. W Teorie wywrotowe. Antologia przęktadów. Red. A. Gajewska. Poznań: Wydawnictwo Poznańskie.

Braidotti, Rosi. 2009. Podmioty nomadycžne. Ucieleśnienie i różnica seksualna w feminiz̨mie wspótcæesnym. Tłum. A. Derra. Warszawa: Wydawnictwa Akademickie i Profesjonalne.

Braidotti, Rosi. 2012. „Etyka stawania-się-niewykrywalnym”. Tłum. J. Bednarek. W Teorie mywrotowe. Antologia przekładów. Red. A. Gajewska. Poznań: Wydawnictwo Poznańskie.

Fisher, Mark. 2009. Capitalist Realism. Is There No Alternative? Winchester-Washington: Zero Books.

Fisher, Mark. 2014. „Terminator vs Avatar.” W \#Accelerate\#. Accelerationist Reader. Red. R. MacKay i A. Avanessian. Falmouth: Urbanomic.

Grosz, Elizabeth. 2009. Przeobrażanie ciał. Tłum. M. Michalski. Biblioteka Online Think Tanku Feministycznego. http://www.ekologiasztuka.pl/pdf/f0071grosz.pdf

Grosz, Elizabeth. 2011. „Darwin i gatunek ludzki”. Tłum. M. Rogowska-Stangret. Præeglad Filozoficzno-Literacki 4 (32).

Kotwasińska, Agnieszka. 2017. „Intensywna podróż: od psychoanalizy do schizoanalizy kina". Praktyka Teoretyczna 3.

Mroczkowski, Bartosz. 2017. „Schizofreniczna materia. O produkcji ciał, pojęć i podmiotowości". Praktyka Teoretyczna 3.

Mrówka, Adrian. 2017. „Félix Guattari, krytyka psychoanalizy i przypadek La Borde”. Praktyka Teoretyczna 3.

Negri, Antonio. 2014. „Some Reflections on »\#Accelerate Manifesto«”. W \#Accelerate\#. Accelerationist Reader. Red. R. MacKay i A. Avanessian. Falmouth: Urbanomic.

Noys, Benjamin. 2013. Malign Velocities. Accelerationism \& Capitalism. Winchester-Washington: Zero Books.

Rudnicki, Cezary. 2017. „Marks bez organów”. Praktyka Teoretyczna 3.

Szopa, Katarzyna. 2017. „Psychoanaliza jako martwy punkt odwiecznej iluzji symetrii, czyli Irigaray spotyka Deleuze'a i Guattariego". Praktyka Teoretyczna 3. 
Joanna Bednarek - filozofka, tłumaczka, członkini redakcji Praktyki Teoretycznej i współpracowniczka Pracowni Pytań Granicznych UAM w Poznaniu, publikowała m.in. w Krytyce Politycznej i Czasie Kultury. Autorka książek: Polityka poza forma: Ontologiczne uwarunkowania poststrukturalistycznej filozofii polityki (2012) i Linie kobiecości: Jak różnica plciowa przeksztatcita literature i filozofie? (2016).

\section{DANE ADRESOWE:}

Międzywydziałowa „Pracownia Pytań Granicznych”

UAM Collegium Chemicum, ul. Grunwaldzka 6, 60-780 Poznań, Polska

EMAIL: bednarekjoanna87@gmail.com

Dawid Kujawa - krytyk literacki, doktorant w Instytucie Nauk o Literaturze Polskiej im. Ireneusza Opackiego UŚ. Autor monografii Wideopoezja. Sžkice (Katowice 2014). Obecnie pracuje nad rozprawa poświęcona powracającym tendencjom awangardowym w polskiej poezji po roku 2000 w kontekście jej polityzacji.

\section{DANE ADRESOWE:}

Instytut Nauk o Literaturze Polskiej im. Ireneusza Opackiego Uniwersytet Śląski plac Sejmu Śląskiego 1, p. 409.

40-032 Katowice

EMAIL: dawid.kujawa0@gmail.com

CYTOWANIE: Joanna Bednarek i Dawid Kujawa. 2017. Jak dziś szukać linii ujścia? Wstęp. Praktyka Teoretyczna 3(25): 325-330.

DOI: $10.14746 /$ prt.2017.3.14

AUTHOR: Joanna Bednarek and Dawid Kujawa

TITLE: How to Look for Lines of Flight Today? Introduction 